\title{
Financial Stability, Monetarism and the Wicksell Connection
}

\author{
DAVID LAIDLER \\ University of Western Ontario and C.D. Howe Institute*
}

In today's discussions of central banking, maintaining macro-financial stability has only recently appeared along-side the pursuit of low inflation as an important policy goal. This is in strong contrast to the earlier literature, where financial stability was often the main concern of the theory of central banking. This theme is explored here first from the point of view of the monetarist tradition, which treated an excess demand for money which the central bank in its capacity as lender of last resort had an obligation to relieve as a central feature of financial crises; and then from that of a later Wicksellian tradition, where co-ordination failures in the inter-temporal allocation of resources that it was monetary policy's task to avoid, were emphasized. Though there are no long-lost sure cures for financial instability awaiting discovery in the older literature, its emphasis on the potential for markets to fail to clear provides a helpful perspective on the phenomenon, often missing from modern models of the conduct of monetary policy.

Keywords: Financial stability, financial instability, crises, co-ordination failure, lender of last resort, inflation, monetarism, forced saving, Wicksell.

JEL Classifications: B13, B22, E31, E32, E58

\section{Inflation Targeting, Macro-financial Stability and Coordination Failures}

Many central banks have learned how to avoid causing inflation in recent years, and, even allowing for a recent resurgence of the problem in a number of places, they are

\footnotetext{
* An earlier version of this paper was presented as the Bank of Canada's 2007 John Kuszczak memorial lecture. I came to value John highly as a colleague during the year I spent at the Bank in 1998-99. He was, as his sometime teacher Bill Scarth said in his (2002) tribute, above all a gentleman, always more interested in contributing to the Bank's work than advancing his own status, and self-effacing to a fault, invariably assuming that if he knew something, then whoever he was talking to must also know it. John's speed on the uptake, and the fact that his tact equaled his modesty, however, usually took the embarrassment out of the confessions of ignorance that this proclivity frequently made necessary. He is much missed, and I hope that memories of his pioneering work on the role of risk aversion in the theory of monetary policy help make this paper an appropriate tribute to him. I am grateful to John's colleagues Chuck Freedman and Pierre StAmant, as well as to Charles Goodhart, Bill Robson and Dimitri Tsomocos for comments on earlier drafts, but absolve them of responsibility for the errors that undoubtedly remain in this one.
}

(C) 2009 David Laidler. Licensed under the Creative Commons Attribution-Noncommercial 3.0 Licence (http://creativecommons.org/licenses/by-nc/3.0/). Available at http://rofea.org. 


\section{LAIDLER Financial Stability, Monetarism and the Wicksell Connection}

therefore spending less time and effort than they once did on fighting this self-created problem, and thus have more intellectual space to worry about other issues. Even before the onset of the current financial crisis in mid-2007, this space was being filled by growing concern on their part for the stability of the financial system, particularly its economy-wide aspects - "macro-financial stability" as it is often termed. This attention is certainly welcome, but it has also created some intellectual discomfort, because the latest theories of monetary policy, specifically those associated with inflation targeting, seem to offer little direct guidance as to how responsibilities for financial stability may be discharged within the context of today's policy regimes.

Viewed in the light of the history of ideas about monetary policy, this is an odd development. To the extent that any body of economic doctrine can be said to have had a definite starting date and specific inspiration, the theory of central banking began during the British financial crises of 1793 and, particularly, of $1797 .^{2}$ It was in reaction to these events that Francis Baring (1797) declared the Bank of England to be the "dernier resort" of the financial system, and, along with Henry Thornton (1797, 1802), set in motion a still-ongoing literature on what this responsibility implied. As late as 1932, Ralph Hawtrey's essay on the Art of Central Banking would still identify its lender of last resort powers as the very foundation of such an institution's ability to influence the economy, before going on to mount a scathing critique of the Federal Reserve system's failure to make either prompt use of those powers in the immediate wake of the stock market crash of October 1929 or any serious effort to break the "credit deadlock" that then ensued. And there is a strong family resemblance between Hawtrey's analysis of the crisis that began in 1929 not to mention that of his sometime assistant Lauchlin Currie (1934), and later work on the same episode by Friedman and Schwartz (1963a).

The idea that, in a monetary economy, the mechanisms whereby the choices of individual agents are coordinated can fail, and the belief that what we call macrofinancial-instability is a symptom of such failure, were pervasive in the literature on monetary theory and policy for two centuries, and by the 1930s, their discussion had divided into two distinct streams. The first of these, associated with Hawtrey and Friedman among others, has already been alluded to, and can fairly be characterized as "monetarist", though this adjective did not enter general usage until Karl Brunner

\footnotetext{
In particular I have in mind here the theories of inflation control in a "cashless economy" which receive their most thorough exposition in Michael Woodford's (2003) Interest and Prices, a book which self-consciously borrows its title from Knut Wicksell's (1898) masterpiece, but which, as will emerge below, does not epitomize "the Wicksell Connection" invoked in the title of this paper.

${ }^{2}$ And the literature on financial stability significantly predates that on central banking. For example, the monetary economics of Richard Cantillon's Essai (1755) was developed earlier, in the wake of the 1721 collapse of John Law's system in France, while the Ayr Bank's 1754 failure is extensively discussed by Adam Smith in the Wealth of Nations (1776).
} 
deployed it in (1968). The second, which can also be traced back to Henry Thornton's ideas about central banking and its influence on the economy, was given the felicitous label "the Wicksell connection" by Axel Leijonhufvud in (1981).

This paper will discuss what each of these approaches had to say about the causes and cures for financial instability. It will discuss the monetarist tradition first, paying some attention to its development of ideas about the central bank's lender of last role, but also to its analysis of the temporary dislocations between the supply and demand for money to which it attributed financial crises. It will be suggested that, inasmuch as this monetarist tradition located the origins of such dislocations in the upswing of the business cycle, the theories that underlie today's inflation targeting regimes do address some, but not all, of the issues it raised. Then the discussion will be directed to co-ordination failures of a kind that the monetarist tradition largely ignored but the "Wicksell connection" emphasized, namely those arising in financial markets with respect to the allocation of resources over time, particularly those associated with the phenomenon of "forced saving". Finally, some current policy implications of these earlier ideas will be discussed, and it will be concluded that, though there are no ready made remedies for today's problems awaiting rediscovery in the older literature, it nevertheless contains enough useful insights to be worth more attention than it is currently given, particularly with regard to the adequacy of inflation targeting as a defense against financial instability, and the measures that are and are not needed to supplement it.

\section{The Monetarist Tradition}

Hawtrey's Art of Central Banking was one of several works in which he expounded a monetary theory of the business cycle and its policy implications that not only descended directly from the contributions of Baring and Thornton, but also, as we have already hinted, prefigured in some important respects the theoretical ideas that underlay in Friedman and Schwartz's monumental Monetary History of the United States (1963), and their only work devoted specifically to the cycle, namely their "Money and Business Cycles" (1963b). To suggest, as we have done, that there is a direct line of development here that merits the label monetarist tradition, is not also, however., to suggest that those involved in it merely repeated the same ideas from the outset without development.

Baring's (1797) contribution is a pamphlet offering a particular interpretation of contemporary institutional arrangements and events, and, though Thornton's Paper Credit (1802) is much more substantial, arguably unsurpassed in the literature of monetary economics before Wicksell's Interest and Prices (1898), certain things which are not in it are central to the concerns of this paper. Crucially, though Paper Credit had a great deal to say about the pivotal position of the Bank of England in the financial system, and its concomitant responsibilities for coping with crises, it did not treat these matters in the context of a regularly recurring business cycle that seemed to be an 


\section{LAIDLER Financial Stability, Monetarism and the Wicksell Connection}

essential feature of the evolution of any market economy, nor, closely related, and its discussion of money wage stickiness notwithstanding, did it make any systematic effort to link its analysis of the monetary system to a theory of the "real" features of that same economy.

These developments came a little later. When, in 1837 Lord Overstone noted that "the state of trade revolves apparently in an established cycle. First we find it in a state of quiescence - next, improvement - growing confidence - prosperity - excitement convulsion - pressure - stagnation - distress - ending again in quiescence", it was already beginning to be understood by those directly involved in financial markets that crises were regularly recurring phenomena that formed but one element in a broader pattern, rather than, as they had appeared to be in the 1790s, shocks to be associated with the exigencies of a war. And by the late 1830s also, what we would now call the theory of monetary policy had already become entangled with a monetary approach to analyzing what was then termed the credit cycle. Furthermore, and central to this paper's concerns, though the relevant essay was not published until (1844), John Stuart Mill had first tentatively explored a particular feature of the above-labeled "convulsion" that might generate "pressure" and "stagnation" in the real economy as early as 1829 or 30, doing so in the context of issues raised by the then rather recent debate between David Ricardo and Thomas Malthus about the logical possibility of a "general glut" of commodities, or as we would now call it, a state of general excess supply, a debate that had been prompted by the sometimes painful adjustments that the British economy went through in the wake of the French wars.

In this famous debate, Ricardo's denial had seemed initially to carry the day, because (in Mill's 1844 words) “. . . whoever offers a commodity for sale desires to obtain a commodity in exchange for it, and is therefore a buyer by the mere fact of his being a seller". Thus, to employ a later phrase, sometimes labeled "Say's Law", Ricardo insisted that supply creates its own demand in the aggregate economy, and that an excess supply of one item must of necessity be matched by an excess demand for another. But, as Mill remarked "This argument is evidently founded on a state of barter", and needs to be qualified in the light of the fact that in a money-using economy, "a superabundance of all commodities relative to money" is indeed a possibility.

Such a disequilibrium, he thought, was particularly likely to arise, albeit temporarily, at times when there is a "want of commercial confidence" and agents like "better to possess money than any other commodity". Mill repeated this argument in his Principles of Political Economy (1848 [1965], p. 574), explicitly noting its relevance to what he there called "commercial crises" characterized by " an excess of all commodities ...[and] an under-supply of money" whose "immediate cause is a contraction of credit" and whose remedy lay in a "restoration of confidence". He stopped short of explicitly noting that such a restoration might be aided by lender of last resort activities on the part of the 
central bank, the provision of liquidity to financial markets in general as well as the granting of aid to particular institutions, but the importance of a commitment to such action for the preservation of commercial confidence had already become something akin to conventional wisdom by the time it was finally enshrined in Walter Bagehot's Lombard Street (1873). ${ }^{3}$

In the Principles, Mill gave an account of the cycle in which a contraction of credit, such as can provoke a temporary failure of markets to function, is a prominent feature of the "reaction" that brings a speculative upswing driven by credit expansion to an end. This account is more descriptive, however, than analytic, and offers little insight into either the mechanisms driving the upswing, or those precipitating the "reaction". 4 But these gaps were in due course filled. The development of what would eventually become the monetarist analysis of the upswing was much advanced by Alfred Marshall in his (1887) essay on "Remedies for Fluctuations in General Prices", where he emphasized the role of what is nowadays known as the "Fisher effect" in driving speculation and credit creation. As prices begin to rise, Marshall argued, nominal interest rates adjust only with a lag, with the resulting fall in real rates creating opportunities for profitable borrowing from the banking system. The associated expansion of bank lending and hence of the money supply leads to an increase in expenditure that in turn puts further upward pressure on prices in a potentially open-ended process that epitomized what Hawtrey (1919) would later refer to as "the inherent instability of credit". This mechanism of Marshall's would in due course find a place in both Hawtrey's theory of the cycle, and Irving Fisher's too. 5

\footnotetext{
${ }^{3}$ As Denis O'Brien (2007, Ch. 7) shows, Bagehot's achievement was not so much to develop new analysis as to expound systematically ideas which, after Baring and Thornton, had already begun to be considerably refined and extended by Thomas Joplin and Vincent Stuckey (probably not quite coincidentally, Bagehot's uncle) in the wake of the 1825 financial crisis, which, it is worth speculating, might also have influenced Mill's thinking about these matters. The last financial crisis in British economic history to involve major insolvencies in the financial sector that were not the result of fraud was that of 1865, and the Bank of England's handling of the Baring crisis of 1890 is widely regarded as having finally removed any doubts that might still have been lingering about its willingness and ability to take responsibility for the stability of the monetary system.

4 In hindsight, though, parts of the relevant passage might be read as hinting at a financial accelerator mechanism. Mill (pp. 542-3) tells his readers that, as the prices of commodities rise, ". . . a great extension of credit takes place. Not only do all whom the contagion reaches employ their credit more freely than usual; but they really have more credit because they seem to be making unusual gains", and also that, once prices are falling, " . . when everyone seems to be losing, and many fail, it is with difficulty that firms of known solidity can obtain the credit to which they are accustomed".

5 Fisher (1896) himself acknowledged Marshall's work, albeit his (1890) Principles of Economics rather than the 1889 essay, as the source of the idea in question, and Marshall in turn would later acknowledge Fisher's empirical application of it. The "real-nominal interest rate" vocabulary was Marshall's own (1887). This distinction, which of course lies at the heart of the Fisher effect, is on more prominent display in Hawtrey's first (1913) account of his cycle theory than in later expositions. The contribution of Fisher's to the literature on the cycle that I have particularly in mind here is that set out in Chapter 4 of The Purchasing Power of Money (1911)
} 


\section{LAIDLER Financial Stability, Monetarism and the Wicksell Connection}

Exponents of this approach to cycle theory generally agreed that the critical factor bringing the upswing to an end was a curtailment of lending and an increase in interest rates provoked by a drain of reserves from the banking system, but there was less of a consensus among them about the details of this mechanism. In nineteenth century discussions, the dominant theme was that an "external drain" of reserves associated with a deteriorating foreign trade balance would come into play, creating for the central bank the problem of calibrating a response strong enough to slow down the economy and correct the trade account, but also sufficiently measured to avoid provoking the "internal drain" that might ensue if nervous agents began to shift the composition of their portfolios away from commercial bank liabilities towards its own, or even towards gold itself.

If a nice balance was not found here, and the readjustment of domestic portfolios was abrupt, then a disequilibrium such as Mill had described would materialize, and a financial crisis would threaten, requiring the central bank to be generous in its granting of credit, while continuing to engineer a longer term contraction. The solution, as summarized by Bagehot (1873) - to lend freely at times of crisis to all solvent borrowers at a high rate of interest - became the centre-piece of the theory and practice of central banking under the gold standard before the First World War, with the high rate of interest playing the dual role of attracting short term capital inflows to stabilize the balance of payments temporarily while precipitating a cyclical downturn in economic activity that would in due course bring about a more durable correction through the trade account. 6

Later contributors to the monetarist tradition, for example Fisher (1911) and Hawtrey $(1913,1919)$, laid more stress than had their predecessors on the role of purely domestic considerations in precipitating a downturn. They noted in particular that, during a cyclical upswing, the demand for currency to support a growing volume of cash transactions would increase, and that this in itself would generate an internal drain that must lead to monetary tightening. Hawtrey suggested that, because wage income would lag behind the economy's expansion, the fall in the public's deposit/currency ratio that its rise would prompt would also be delayed until rather late in the upswing. When this finally came, therefore, it could (not must) provoke a reaction in the rate of money growth sharp enough to precipitate a crisis whose central features would be a sharp increase in the banks' reserve/deposit ratio, and a further falls in the deposit/currency ratio too.

As late as (1963b) Friedman and Schwartz, citing Phillip Cagan's work (See Cagan 1965), also pointed to variations in the deposit/currency ratio as the dominant factor

\footnotetext{
6 The relevance of all this to recent crises under pegged exchange rate regimes is obvious enough. One of the disadvantages of such arrangements is that their maintenance requires monetary stringency just when domestic conditions make it undesirable. A flexible exchange rate removes this requirement, but this is only an advantage if, under such a regime, some other arrangement - for example a credible inflation target - exists to underpin stable price level behaviour in the longer run.
} 
driving cyclical variations in the rate of money growth and thence in the economy itself, arguing that, at the beginning of the upswing, "redundant money balances are initially in the hands of asset holders with a high ratio of deposits to currency. As the redundant balances are diffused, they spread to a more nearly representative group in the population ... [so that] . . . the deposit-currency ratio . . . reaches a peak around mid-expansion, and falls." (p. 232). The continuity between this account of the factors bringing on the cycle's upper turning point and Hawtrey's is surely striking.

\section{Prescriptions for Avoiding Crises in the Monetarist Tradition}

Now as is well known, Friedman's prescription for, among other things, avoiding an excessively vigorous upswing, and hence for forestalling financial crises too, was a money supply growth rule. This proposal was absent from earlier work in the monetarist tradition, for the simple reason that its efficacy requires stability of the economy's aggregate stock demand for money function, and this particular idea was new in the 1950s. The broader monetarist postulate that the key to avoiding financial instability lay in eliminating, or at least mitigating, the cycle, particularly its potentially explosive upswing, was, however, present in the theory of central banking from the very outset, though opinions as to how this could be accomplished evolved continuously over time as one remedy after another was tried and found wanting.

At first, after the Bank of England's convertibility obligations had been "temporarily" suspended in 1797 - they would not be re-instated till 1821 - and before the fact of the cycle itself had been recognized, the mere restoration of convertibility was sometimes touted as sufficient to remove the threat of financial crises, at least in peace-time. When this was seen to be insufficient (as first became apparent with the crisis of 1825) similar hopes were then vested in setting a 100 per cent marginal bullion reserve requirement against the Bank of England's note issue while freezing and then phasing out the note issue of the commercial banks. These measures were intended to speed up the response of the money supply to any incipient balance of payments problem and hence to prevent any cyclical upswing getting out of hand. They were instituted by the 1844 Bank Charter Act, but failed to have their desired effect, having been rendered obsolete by institutional developments even before their introduction. By 1844, the Bank of England's deposit liabilities, rather than its note issue, had already become the reserve asset of choice for the commercial banking system, whose own chequable deposit liabilities were also well on their way to becoming the dominant component of the money supply.

Subsequent orthodoxy, epitomized by Bagehot's work, then began to put its faith in the stabilizing influence of the confidence that a clear commitment by the Bank of England to its lender of last resort role might generate, and this factor does indeed seem to have mitigated the seriousness of crises from the 1860s onwards, though it stopped far short of eliminating the cycle per se, which is one reason why the post-1880 literature 


\section{LAIDLER Financial Stability, Monetarism and the Wicksell Connection}

paid so much attention to devising further specific stabilization schemes of one sort or another. Thus, in (1887) Marshall proposed indexation, of both debt contracts to eliminate the Fisher effect, and of wages to counter the effect of their nominal stickiness on the time path of employment, while (beginning in 1912) Fisher advocated the indexation of money itself in the form of a compensated dollar, and subsequently tried hard to get Congress to legislate a price level stability goal for the newly founded Federal Reserve system. Taking another tack, Wicksell and Hawtrey recommended discretionary interest rate variations engineered by the central bank that were to be explicitly aimed at stabilizing the price level, proposals that are recognizably the predecessors of today's inflation targeting regimes. ${ }^{7}$

These regimes, in short, have a long intellectual pre-history during which the stabilization of inflation was by and large not treated as policy goal separate and distinct from mitigating the cycle and maintaining financial system stability, but as a key means of promoting precisely these ends. They also seem to have had some success as far as mitigating the cycle is concerned. Canada is but one among several economies that have not seen anything worth labeling a recession since the early 1990s - at the time of writing the outcome of the current slowdown is uncertain - and, though the Fed. is not a formal targeter, it too delivered modest and reasonably stable inflation and an impressive real performance as well until recently - albeit interrupted by a brief recession at the turn of the millennium which was followed by an uncomfortable burst of CPI inflation that moved above 4 per cent and should have caused much more concern than it did. Taken overall, however, though cyclical fluctuations have been significantly damped since about 1990, financial stability has proved much harder to maintain, even among formal inflation targeters. The latest upheaval may well be the most violent we have seen since the 1930s, but it is by no means the first financial crisis to occur in recent years, even as monetary policy world-wide began to pay increasing attention to inflation control.

\section{The Wicksell Connection}

In part, this should be no surprise, because there is more to economic life than monetary policy disturbances: the two British crises of the 1790s that set the theory of central banking in motion in the first place were responses to the outbreak of war and a subsequent invasion scare, not to previously excessive lending by the Bank of England, though it certainly indulged in that soon afterwards; attempts to control inflation through pegging exchange rates at over-optimistic levels as seen in Europe in 1991, Asian countries in the mid 1990s and Argentina before 2000, have also often come to grief; and it is hard to blame Russia's 1998 debt default on the monetary policies of any of the

\footnotetext{
7 Note that Wicksell's advocacy of such measures arose in the context of an analysis of secular inflation, rather than of a monetary theory of the cycle as did Hawtrey's. See below for a more extensive discussion.
} 
countries whose financial systems were subsequently rattled by it. But this still leaves us needing explanations for the more recent dot-com boom and bust, not to mention what we are now learning to call the sub-prime mortgage crisis, and the literature reviewed so far in this paper does not provide one, nor indeed did it for either the stock market crash of 1929 which ushered in the subsequent Great Contraction or for the collapse of the Japanese "bubble economy" which preceded that country's "lost decade" of economic expansion. None of these crises was precipitated by any obvious exogenous shock, nor by attempts to maintain an unsustainable exchange rate, nor, crucially, were they heralded by a significant burst of broadly-based price inflation. ${ }^{8}$

Further help here is to be found in those elements of the inter-war literature whose often disparate components are linked by what Leijonhufvud called "the Wicksell connection", a label that in today's intellectual climate is easy to misinterpret, because Wicksell's current reputation is as a pioneer of models of inflation that focus on the interaction between the "market" and "natural" rates of interest, and in particular on the idea that equality between these two is the key pre-condition for monetary policy to be exerting a "neutral" - i.e. neither upward nor downward - influence on the inflation rate. Wicksell is explicitly recognized, that is to say, as having anticipated the very models that underlie today's otherwise monetarist inflation targeting regimes. So he did, but these elements of his work go back at least to Thornton (1802) and were never far from the centre of discussions of monetary matters thereafter, in which the "market-natural" terminology was also commonly deployed. Wicksell refined these aspects of the monetarist tradition, that is to say, but he did not invent them, and they are not what Leijonhufvud had in mind when he coined his label. ${ }^{9}$

Where Interest and Prices broke new ground was, first, in relating the natural rate to the then emerging microeconomic analysis of production, more specifically, in treating it the marginal productivity of capital (he explicitly used this term only in 1907 however), and, second, in suggesting that disturbances to monetary neutrality should be thought of as mainly originating in the real economy, rather than in the monetary sector. Consistent with this view, Wicksell was no exponent of a monetary theory of the business cycle, but of a real theory that focused on productivity shocks, and in which monetary factors played at most a secondary, albeit potentially amplifying, role; and he conceived of his

8 But see the comment above about US CPI inflation rising above 4 per cent during the run-up to the recent crisis before being reined in by Fed. policy, and note that in the last years of its bubble economy, Japan's inflation rate did move systematically upwards, though it had not reached even 3 per cent when the bubble burst. The evidence is not all in on these bouts of instability.

9 Wicksell himself was not aware of Thornton's work until rather late in his life, but he was well acquainted with much of the subsequent so-called "Banking School" literature on which Thornton had, as Neil Skaggs (1995) has shown, exerted a strong influence. For an example of the use of "marketnatural interest rate" terminology in a highly visible source see, for example Mill's Principles,(p. 648) : "the natural rate .. . about which the market rate oscillates ..." 


\section{LAIDLER Financial Stability, Monetarism and the Wicksell Connection}

analysis of inflation as having most relevance to its secular rather than cyclical behaviour. Wicksell's theory of inflation, moreover, differed from that of his contemporaries in stressing not the influence of deviations of the market from the natural rate of interest on money growth, and thence on prices, but their direct capacity to create discrepancies between saving and investment. He argued that when the interest rate was at its neutral level and saving equaled investment "as if" in a frictionless barter economy, there would be no net credit creation on the part of the banking system and price level stability would prevail.

Wicksell's characterization of monetary neutrality was in fact internally inconsistent under some circumstances - most obviously, in a growing economy where zero credit creation would imply falling prices - and it set in motion a literature which soon came to focus on the consequences of a deviation of the market rate of interest from its neutral level, not so much for price level behaviour as he had done, as for the evolution of real economic variables. These consequences were seen to be of particular relevance to the analysis of the cycle and the role of financial system in generating and/or amplifying it, and they were thoroughly investigated in the inter-war years in the literature that Leijonhufvud (1981) surveyed..

\section{Forced Saving}

One strand in that investigation, to which Wicksell's Swedish successors - the so-called Stockholm School - made significant contributions, and which eventually led, through Keynes's (1930) Treatise on Money to his (1936) General Theory, came to emphasize the influence of the interaction of saving and investment on the current level of real aggregate demand and hence of employment, but is not quite central to the concerns of this paper. Another, which stressed the consequences of such a co-ordination failures for the time path of the capital stock and hence the evolution of the economy's supply side, does however require our attention, however, both in its so-called Austrian version, developed mainly by Ludwig von Mises $(1912,1924)$ and Friedrich von Hayek (1931), but also in that of Keynes' sometime student, collaborator, and eventual critic, Dennis Robertson. ${ }^{10}$ The key concept of this analysis is "forced saving", an idea which, as Hayek (1932) shows, made its first appearance at the very beginning of the nineteenth century - in Thortnon (1802) among other places - but whose full significance was not fully appreciated till much later.

Forced saving may be explained as follows. When the market rate of interest lies

\footnotetext{
${ }^{10}$ Wicksell's work was fully acknowledged by the Austrians from the outset as in, for example, Mises (1912), and also in the Swedish literature. With Robertson and Cambridge economists more generally, matters are less clear. Not until Keynes's Treatise (1930) do we find an explicit mention of Wicksell's influence. And yet a paper by Wicksell, summarizing his key contributions, appeared in the Economic Journal in 1907, and it is hard to believe that it went unread for two decades, even in Cambridge.
} 
below its neutral value, agents are thereby encouraged to borrow from the banking system to undertake investment plans that, should they come to fruition, will eventually enable the economy's supply of consumption goods to be increased. A below neutral interest rate, however, is a disequilibrium phenomenon, signaling to would-be investors a greater willingness than in fact exists on the part of agents in general to sacrifice current consumption for the sake of increasing it later. This investment takes place nevertheless, because the money that banks create as they make loans enables those who borrow from them to outbid others for resources, to force saving upon them. A stock of capital, for whose future output there is in fact no demand, thus begins to build up, and if and when the interest rate rises to its neutral level, the imbalance thus created is revealed along with an inability on the part of borrowers to service their debts.

In this analysis, the main danger inherent in over-rapid credit creation is not its tendency to create generalized price-level inflation which can end in a crisis characterized by the excess demand for money that figures so prominently in the monetarist tradition, but its capacity to distort the inter-temporal structure of relative prices so that an excess demand for current consumption goods develops even while soon-to-be-revealed-asunwanted capital goods accumulate. The fundamental feature of the financial crisis that marks the end of a bout of forced saving brought about by credit creation is thus not so much the sudden emergence of an excess demand for money, though this might well occur, but rather the revelation of a more basic dislocation within the real economy, specifically in the inter-temporal allocation of resources. As Lionel Robbins, a leading exponent of the Austrian version of such reasoning described the unwinding of such a state of affairs: "Sooner or later the initial errors are discovered. And then starts a reverse rush for liquidity. The Stock Exchange collapses. There is a stoppage of new issues. Production in the industries producing capital goods slows down. The boom is at an end" (1934, p. 42).

Now the Austrians were prone to treat logical possibilities suggested by their arguments as logical necessities, and sometimes pushed them further than they would really go. In particular they argued that any net credit creation on the part of the banking system would always lead to forced saving and end with events such as Robbins described. This was because they were innocent of the analysis of how such a process, if fully anticipated, can be an equilibrium one, in which holders of cash balances reduce current consumption voluntarily and make resources available for other uses, of which capital accumulation might be one. ${ }^{11}$ But this does not mean that the consequences that

\footnotetext{
${ }^{11}$ A more than embryonic version of such analysis appeared, under the label induced lacking in Dennis Robertson's (1926) Banking Policy and the Price Level, where Keynes is credited with having originated it. This book, however, deployed a special vocabulary of daunting eccentricity that rendered it close to unreadable even for native English speakers, let alone Austrians and others, and surely diminished its impact and influence. Moreover, Robertson himself treats this analysis as simply
} 


\section{LAIDLER Financial Stability, Monetarism and the Wicksell Connection}

the Austrians warned about are ruled out in all circumstances. A below-neutral interest rate and associated unanticipated credit creation surely can distort inter-temporal relative prices, and create forced saving for a while too, until expectations catch up, and it is possible for things then to go badly wrong in the ways that Robbins described. Furthermore, in a growing economy, such a process can proceed unaccompanied by overall price inflation, provided that the rate of growth of nominal money that emerges from it does not exceed that of the demand for real balances associated with rising real income.

Quite crucially, therefore, desirable though maintaining low or even zero inflation may be as a means of promoting financial stability, the analysis of forced saving warns us that the achievement of this goal stops short of providing any cast-iron guarantees; and, not least because this analysis also seems to capture certain features that emerge in the real economy in the wake of financial crises - "see through" office buildings, large accumulations of unwanted "high-tech" equipment, inventories of newly built but unsaleable luxury houses etc. - it also prompts quite practical questions about what monetary policy makers ought to do about to prevent it, either instead of or in addition to maintaining low inflation.

Here the Austrians are not much help. Not having a theory of anticipated inflation, they concluded that the only way to avoid forced saving would be to eliminate credit creation by the banks altogether, except where it was needed to offset shifts in the demand for money, in short to hold nominal expenditure in the aggregate constant, and hence, in a growing economy, to generate steady deflation. Of course they also understood that precision here was impractical, which is what led Hayek (1931), for example, to conclude that "The best we may hope for is that the growing information of the public may make it easier for central banks to both to follow a cautious policy during the upswing of the cycle, and so mitigate the following depression, and to resist the wellmeaning but dangerous proposals to fight depression by "a little inflation" (p.109)

This last phrase at first sight gives the impression of anticipating much later monetarist denials of an exploitable inflation-unemployment trade-off, but the "inflation" to which Hayek here refers is inflation of the money supply, not of the price level, and the phrase should be read as advising against using expansionary monetary policy to fight depression once it had started, the very opposite of monetarist doctrine as expounded by Hawtrey and Currie among his contemporaries, and Friedman and Schwartz among his successor. And this advice in turn was just one component of a more general Austrian opposition to any kind of expansionary measure once a boom had come to an end. Again in Hayek's words: "The only way permanently to "mobilise" all available resources is . .

one variety of forced saving, rather than, as we now would, the full-equilibrium paradigm around which any exposition of the topic as a whole should revolve. 
not to use artificial stimulants - whether during a crisis or thereafter - but to leave it to time to effect a permanent cure by the slow process of adapting the structure of production to the means available for capital purposes" (p. 87)

Echoes of such views can still be heard today in arguments that the Fed. would have done better to refrain from expansionary policies in the wake of the dot-com bubble, on the grounds that these merely permitted imbalances to persist and to re-appear later in the housing market, and that it should similarly have let the ensuing sub-prime mortgage crisis take its course. But we may let Lionel Robbins (1971), who himself held similar views in the 1930s, have the final word on this point of view: "Assuming that the original diagnosis of excessive financial ease and mistaken real investment was correct - which is certainly not a settled matter - to treat what developed subsequently in the way which I then [i.e. in the early 1930s] thought valid was as unsuitable as denying blankets and stimulants to a drunk who has fallen into an icy pond on the ground that his original trouble was overheating" (p. 154). This is not, of course, to deny that stimulants may inadvertently be excessively administered from time to time in such cases, and therefore that the Fed. might have made just such a mistake in persisting too long with its expansionary measures in recent years, and that it needs to take care not to repeat such an error this time around.

In the 1930s, nevertheless, the Austrians thought that policy nihilism was logically implied by their analysis of forced saving, because it seemed to tell them that underlying any financial crisis was a real disequilibrium involving an excess supply of capital goods and an excess demand for consumption goods. To undertake public works spending or to stimulate business investment would merely exacerbate the former, and to encourage consumer expenditure the latter. The often parallel and sometimes more subtle treatment of the same issues by Dennis Robertson however, led him to so such conclusion.

Robertson (1915) began as an exponent of the same tradition in real business cycle theory in which Wicksell worked, and it was only in the 1920s that he began to integrate monetary and financial factors into his treatment of it. As do modern real business cycle theorists, Robertson viewed fluctuations in output stemming from unevenness in the pace of technical progress as "appropriate", and saw their accommodation as being an important task for the financial system. As he put it "I do not feel confident that a policy which in the pursuit of stability of prices, output and employment had nipped in the bud the English railway boom of the forties, or the American railway boom of 1879-71, or the German electrical boom of the nineties, would have been on the balance beneficial to the populations concerned" (1926, p. 22) But Robertson also understood that the workings of the financial system could permit what began as appropriate fluctuations to take on "inappropriate" dimensions fed by forced saving which might even sometimes proceed without generally rising prices, and could end badly. In (1928), for example, referring to the then ongoing US boom, he suggested that "The Federal System (sic) cannot be wholly 


\section{LAIDLER Financial Stability, Monetarism and the Wicksell Connection}

absolved of the charge of having burgled from the public" (p.144) and he also posed a prophetic question, namely: "if that great country should ever become even temporarily saturated with fifty-story buildings and motor cars, can we be certain that any purely monetary policy would meet the needs of the situation?" (p. 41, Robertson's italics).

For Robertson, then, "The aim of monetary policy should surely be not to prevent all fluctuations in the general price-level, but to permit those which are necessary to the establishment of appropriate alterations in output and to repress those which tend to carry the alterations in output beyond the appropriate point." (p.39), but he also advocated mild deflation as a long run monetary policy target, as did the Austrians. Clearly, then, he did not regard a degree of cyclical fine-tuning as precluding the pursuit of secular price level goals, and this gives his work a rather modern touch, anticipating those who doubt that inflation targeting is a sufficient goal for monetary policy, and would prefer central banks to be flexible enough to pay at least a little attention to preempting asset market instability before it gets out of hand. ${ }^{12}$ More fundamentally, with his analysis of the potential for forced saving to create financial instability, he provided a framework within which these same commentators' worries about the destructive potential of cumulating imbalances can be treated as integral to a general theory of monetary policy.

But, it should be added immediately, Robertson was much better at formulating such a general framework in the abstract than at developing the details needed to apply it to practice.

Like all of his British contemporaries in the inter-war years his immediate policy concern was how to cope with already existing unemployment, and like most of them, he was pragmatic and flexible, advocating expansionary monetary policy, but, because, as we have seen above, he had doubts about its efficacy in depression conditions, expansionary fiscal policies too.

The reason that Robertson was able to reach such policy conclusions, the diametric opposites of Austrian doctrine, was remarkably simple: he recognized the significance of the fact that over-investment fed by forced saving affected particular sectors of the economy, rather than its overall capital stock, and that the onset of a crisis originating in one or more sectors would still leave room to expand expenditures elsewhere to useful ends. As he put it when defending public works expenditures: "What, after all, can be more sensible than that the Central Government should organise a collective demand for telephone equipment, or the local government a collective demand for municipal lavatories, to take the place of a demand for ships or steel rails which has rightly and reasonably fallen temporarily away?" (1928, p. 178). Substitute "highways, bridges and public transit equipment" along with "fibre-optic cable and luxury homes" in the

${ }^{12}$ The views are particularly associated with the Bank for International Settlements. See for example, Andrew Crockett (2003), and Claudio Borio and William White (2004) 
Review of Economic Analysis 1 (2009) 60-79

appropriate places in this passage, and this passage surely takes on an element of current relevance.

\section{Financial Instability and Monetary Policy Today}

Now we should not claim too much on behalf of the older literature that has been so selectively surveyed in this paper. It conveys no precise instructions for casting some magic policy bullet that today's central banks can confidently fire at financial stability problems. But this literature does perhaps offer some clues about how they might at least build better observation-posts from which to view the challenges that these problems pose.

Today's monetary policy makers interpret the information available to them in terms of models built according to the best professional practice currently available, and these models are crucial to the design of their responses as well. So far so good, and there should be no objection to the fact that, in those models, the economy's endowments are specified, along with the tastes of the agents that inhabit it, and the technology available to them, as well as the rules that govern the workings of the market; nor is there anything wrong with then deriving equations characterizing the strategies that maximizing agents will adopt. But those equations are then solved as a system in order to understand how this economy will evolve in response to exogenous impulses, including those emanating from policy, and here we encounter a problem. To take this last, seemingly purely technical step, is to presuppose that the model's market has a counterpart in real world social arrangements that in fact enable agents' plans always to be executed and coordinated. Those social arrangements, however, are what we call the monetary and financial systems, for which the "market" is no more than a metaphor. Thus, to assume that, in the real world, aggregate behaviour can always be interpreted as a set of solutions to equations describing agents' strategies is to postulate that the monetary and financial systems always function properly to coordinate them. When they don't, it is small wonder that models of monetary policy that rely on this assumption have trouble in getting to grips with the problems that then arise.

To put the same point in another way, a common postulate linking the monetarist tradition and the Wicksell connection is that they treat monetary and financial instability as a symptom of co-ordination failures that arise from imperfections in the system's workings. In the monetarist tradition, a discrepancy between the supply and demand for money, and hence the supply and demand for output as a whole, is what matters, while the Wicksell connection emphasizes dislocations between saving and investment and hence in the allocation of resources over time. The stylized facts generated by real world economies, moreover, seem to suggest that both traditions have some insights to offer us.

Success in stabilizing the inflation rate does seem to help stabilize the real economy and reduce the scope for financial instability to develop, as the monetarist tradition suggests, 


\section{LAIDLER Financial Stability, Monetarism and the Wicksell Connection}

but it doesn't eliminate those problems altogether, just as the Wicksell connection warned. Monetarist and Wicksellian insights into disequilibrium phenomena might both be fruitfully integrated into today's approaches, therefore.

This looks easier in the monetarist case. Central banks are well aware of their lender of last resort role, and have shown themselves willing to play it. This would not be the case did they not continue to attach some significance to interactions between the supply and demand for stocks of liquid assets for their ability to influence the economy and to the possibility of excess demands for such assets developing in times of crisis, whose elimination is the essential aim of such measures. Their standard policy model for tranquil times, which nevertheless ignores these considerations is, furthermore, a particular variation on the two-interest rate apparatus deployed throughout the monetarist tradition's development, albeit one that suppresses the crucial role played by active money creation on the part of the banking system in policy's transmission mechanism. But if this feature were again to begin to play a routine role in policy thinking - note that I here stop short of saying day to day policy implementation - that would be sufficient to render the monetarist approach to dealing with financial instability through lender of last resort activities simply a particular application of a generally used framework. ${ }^{13}$

The Wicksell connection deals with the influence of monetary policy on relative prices and on saving and investment, and it is a remarkable feature of monetarism, particularly in its more recent manifestations, and of today's standard monetary policy model too, that neither seems to attach any special significance to these latter variables. Hawtrey's isolated 1913 discussion of the accelerator mechanism notwithstanding, his later work focused only on fluctuations in inventory investment as a factor driving private sector borrowing from the banks, and, in Friedman and Schwartz (1963b), investment appeared only as a major component of autonomous expenditure that in turn was the driving variable in a "Keynesian" explanation of fluctuations in nominal income, presented there as discredited by the work of Friedman and David Meiselman (1963). And Woodford's (2003) key results on how to stabilize inflation are developed in a simple version of his "cashless" standard model that reflects traditional monetarist views about the unimportance of investment by abstracting entirely from it.

The cyclical behaviour of expenditure on capital goods, however, has long been known to be every bit as distinctive as those of money, output and prices, and it invites explanation not only to satisfy scientific curiosity, but also, if the insights associated with the Wicksell connection are correct, because of its particular relevance to the intertemporal coordination failures that they highlight as undermining financial, not to mention real, stability. Extending the standard model to accommodate these factors presents a challenge that is more daunting than the re-integration an active role for

13 I have elaborated the argument of this paragraph at some length in Laidler (2003) 
monetary and financial aggregates into its account of policy's transmission mechanism. And this task is not made easier by the need for disaggregation implicit in Robertson's surely correct observations about the tendency of forced saving and its consequences to be concentrated in any particular instance on specific sectors of the real economy rather than to spread right across it.

Presumably over-investment fed by forced saving can get under way in a particular sector either because some technological improvement gives rise to enhanced expectations about the real returns to be earned from investing there that then get out of hand, or because the introduction of some new method of channeling credit into it creates profit opportunities whose true magnitude might be just as easy to over-estimate. ${ }^{14}$ The former type of shock has, of course been much analyzed, and in recent experience seems to be what drove the dot-com bubble. The latter is worth more attention, for it was surely new techniques for financing mergers and acquisition that underlay the stock market boom and bust of 1987, and new kinds of mortgages not to mention methods of securitizing them that created the recent US housing bubble. These considerations in turn suggest that localized innovations both in production itself and in the technology of financial transactions need to be modeled as possible sources of disequilibrating shocks to the financial system as a whole. Though the financial accelerator mechanisms that are nowadays attracting so much attention, with their emphasis on the effects on credit creation of variations in the value of particular assets as collateral, are surely adaptable to such a task, it is nevertheless one that is more easily proposed than accomplished. ${ }^{15}$

\section{Concluding Observations on Policy}

In any event monetary policy's traditional tools are economy-wide in their impact, and do not seem well adapted to addressing sector-specific problems even when they are well understood and their consequences threaten to be economy-wide, and this leads to three concluding observations. First, and surely uncontroversial in the light of recent events: central banks should not throw away their lender of last resort tools just because they are successful in controlling inflation, because they will surely need them from time to time to deal with the aftermath of crises stemming from other sources, including of course inter-temporal co-ordination failures fuelled by forced saving; second, if financial stability problems are to be pre-empted before they come to a head, that task needs tools that can be deployed on a sector-specific basis while not interfering with the pursuit of

\footnotetext{
${ }^{14}$ And, as Charles Goodhart and Dimitrios Tsomocos have both reminded me, at this point in the argument, there emerges a link between analysis of financial instability along Robertsonian lines and the post-Keynesian approach to these issues epitomized by the work of Hyman Minsky (eg. 1982), whose exploration would surely be worthwhile.

15 I am indebted to Bill Robson for the suggestion that financial innovations themselves might be a source of relative price distortions that can in turn create forced saving, and to Pierre St-Amant for drawing my attention to the relevance of financial accelerator analysis in this context.
} 
LAIDLER Financial Stability, Monetarism and the Wicksell Connection

stable inflation in the economy overall, so perhaps regulation and supervision, and even moral suasion, are more integral to the conduct of monetary policy than we have tended to think in recent years; and finally, perhaps we should learn to live more comfortably than we do at present with the possibility that, even under well designed monetary policy regimes, things will still go wrong from time to time in an economy where innovation, both in the production of goods and services, but also in the operations of the financial sector itself, is ongoing.

\section{References}

Bagehot, W. (1873), Lombard Street: a Description of the Money Market, London, P. S. King \& Son.

Baring, F., (1797), Observations of the Establishment of the Bank of England and on the Paper Circulation of the Country, London (reprinted, New York, Augustus Kelly, 1967).

Borio, C. \& W. White (2004), Whither Monetary and Financial Stability - the Implications of Evolving Policy Regimes, BIS Working Paper \# 147, Basel, BIS.

Brunner, K. (1968), The Role of Money and Monetary Policy, Federal Reserve Bank of St. Louis Review 50 (July) 8-24.

Cagan, P. (1965), Determinants and Effects of Changes in the US Money Stock 18751960, New York, NBER.

Cantillon R. (1755), Essai sur la nature du commerce en general (edited by H. Higgs with an English Translation, London, Macmillan 1931),

Crockett, A. (2003), Central Banking under Test: opening address, BIS conference on Monetary Stability, Financial Stability and the Business Cycle, Basel, BIS.

Currie, L. (1934), The Failure of Monetary Policy to Prevent the Depression of 1929-32, Journal of Political Economy, 42 (April) 145-77.

Fisher, I. (1896), Appreciation and Interest, AEA Publications, Series Three, 2:331 - 442.

Fisher, I. (1911), The Purchasing Power of Money, New York, Macmillan (2nd edition, 1912).

Friedman M. \& D. Meiselman (1963), The Relative Stability of Monetary Velocity and the Investment Multiplier in the United States, 1897-1958, in Commission on Money and Credit, Stabilization Policies, Englewood Cliffs, N.J., Prentice Hall.

Friedman M. and A. J. Schwartz (1963a), A Monetary History of the United States 18671960, Princeton, N.J., Princeton University Press for the NBER.

Friedman M. and A. J. Schwartz (1963b), Money and Business Cycles, Review of Economics and Statistics (Reprinted in M. Friedman, The Optimum Quantity of Money, London, Macmillan

Hawtrey, R. G. (1913), Good and Bad Trade London, Constable.

Hawtrey, R. G. (1919), Currency and Credit London, Longmans Group. 
Review of Economic Analysis 1 (2009) 60-79

Hawtrey, R. G. (1932), The Art of Central Banking London, Longmans Group.

Hayek, F. A. von, (1931), Prices and Production, London, Routledge.

Hayek, F. A. von, (1932), A Note on the Development of the Doctrine of Forced Saving, Quarterly Journal of Economics, 47, (Nov.) 123-33.

Keynes, J. M., (1930), A Treatise of Money (2 Vols.) London, Macmillan.

Keynes, J. M., (1936), The General Theory of Employment, Interest and Money, London, Macmillan.

Laidler, D. (2003), Monetary Policy without Money: Hamlet without the Ghost, in Bank of Canada: Macroeconomics, Monetary Policy, and Financial Stability: a Festschrift in Honour of Charles Freedman, Otttawa.

Leijohnhufvud, A. (1981), The Wicksell Connection - Variations on a Theme, in Information and Coordination, Oxford, Oxford University Press.

Marshall, A. (1887), Remedies for Fluctuations in General Prices, (reprinted in A. C. Pigou (ed.) Memorials of Alfred Marshall, London, Macmillan 1925).

Marshall, A. (1890), Principles of Economics, London, Macmillan.

Mill, J. S. (1844), On the Influence of Consumption on Production, in Some Unsettled Questions of Political Economy, London, (Reprinted Clifton New Jersey, Augustus Kelley, 1974).

Mill, J. S. (1848), Principles of Political Economy, with Some of Their Applications to Social Philosophy, (7th ed. 1871, Reprinted, Edited by J. M. Robson, Toronto, University of Toronto Press, 1965).

Minsky, H. P. (1982), Can "It' Happen Again? Essays on Instability and Finance, Armonk NY, M. E. Sharpe.

Mises, L. von (1912) Theorie des Geldes und der Umlaufsmittel (2nd edition 1924, translated by H. E Batson, The Theory of Money and Credit, London, Jonathan Cape, 1934).

O'Brien, D. (2007), The Development of Monetary Economics, Cheltenham UK, Northampton MA, Edward Elgar.

Overstone, Lord (Samuel Jones-Loyd) Reflections Suggested by a Perusal of Mr. J. Horsley Palmer's Pamphlet on the Causes and Consequences of the Pressure on the Money Market, (Reprinted in Tracts and Other Publications on Metallic and Paper Currency, London, privately printed, 1857).

Robertson, D. H. (1915), A Study of Industrial Fluctuation, London, P. S. King \& Son.

Robertson, D. H. (1926), Banking Policy and the Price Level, London, Macmillan.

Robertson, D. H. (1928), Money (3rd. ed.) London, Nisbett .

Robbins, L. C. (1934), The Great Depression, London, Macmillan.

Robbins, L. C. (1971), Autobiography of an Economist London, Macmillan.

Scarth W. (2002), Memorial lecture: Contributions of John Kuszczak, http://www.bankofcanada.ca/en/conference/2002/MemorialLecture-v2.pdf. 
LAIDLER Financial Stability, Monetarism and the Wicksell Connection

Skaggs, N. (1995), Henry Thornton and the Development of Classical Monetary Economics, Canadian Journal of Economics, 28 (Nov.) 1212-27.

Smith, A. (1776), An Inquiry into the Nature and Causes of the Wealth of Nations, London (Reprinted ed. R. H. Campbell and A. S. Skinner, Oxford, Oxford University Press, 1976).

Thornton, H. (1802), An Enquiry into the Nature and Effects of the Paper Credit of Great Britain, London, (reprinted, with an Introduction by F. A. von Hayek, London, George Allen and Unwin 1939).

Wicksell, K. (1898), Interest and Prices, (translated R. F. Kahn, London, Macmillan for the Royal Economic Society, 1936).

Wicksell, K. (1907), The Influence of the Rate of Interest on Prices, Economic Journal, 17 (June) 213-20

Woodford, M. (2003), Interest and Prices, Princeton N. J., Princeton University. 